\title{
ScIDoC
}

\author{
International Journal of Dentistry and Oral Science (IJDOS) \\ ISSN: 2377-8075
}

\section{The Role of CD44 Cancer Stem Cell Marker in the Development and Progression of Lymph Node Metastasis in Oral Squamous Cell Carcinoma}

Research Article

Ahmed M. Hussein ${ }^{1}$, Asmaa M. Zahran², Mohamed Badawy ${ }^{3}$, Hany G. Gobran ${ }^{4}$, Mohamed F. Edrees $^{5}$, Enas M. Omar ${ }^{6{ }^{*}}$

${ }^{1}$ Lecturer of Oral and Maxillofacial Pathology Department, Faculty of Dentistry, Assiut University, Assiut, Egypt.

${ }^{2}$ Associate Professor of Clinical Pathology Department, South Egypt Cancer Institute, Assiut University, Egypt.

${ }^{3}$ Lecturer of Oral Biology Department, Faculty of Dentistry, Assiut University, Assiut, Egypt.

${ }^{4}$ Associate Professor of Oral Biology Department, Faculty of Dentistry, Al-Azhar University (Boys Branch), Egypt.

${ }^{5}$ Associate Professor of Oral Medicine and Periodontology Department, Faculty of Dentistry, Al-Azhar University, Assiut, Egypt.

${ }^{6}$ Lecturer of Oral Pathology Department, Faculty of Dentistry, Alexandria University, Alexandria, Egypt.

\section{Abstract}

\begin{abstract}
Introduction: Oral squamous cell carcinoma (OSCC) management is challenging due to high tendency of local invasion and metastasis. Cancer stem cells hold high significance as they have self-renewal ability, which further allows cancer progression and metastasis. Hence, it is crucial to evaluate different specialised markers for stem cells, such as CD44, to detect their role in tumour metastasis. Flow cytometry (FCM) offers a quick and automated assessment of ploidy status and cell proliferation of the neoplasm by resolving the nuclear DNA contents.

Aim of the study: The objective of this paper is to evaluate the CD44 expression and analyse DNA content by FCM to predict the expansion of lymph node metastasis in patients with OSCC.

Material and Methods: 50 paraffin-embedded tissues of metastatic and non-metastatic lymph node OSCC were immuno stained by CD44 for assessing cancer stem cell activity in each lesion. Furthermore, each selected tissue underwent flow cytometric analysis to demonstrate the DNA activity between the tested groups.

Results: The CD44 expression in OSCCs showed a marked difference between the metastatic and non-metastatic lymph node cases. Furthermore, flow cytometric analysis of the DNA parameters between the tested groups revealed a powerful difference of DNA ploidy. The S-phase fraction (SPF) between the groups showed no compelling result. All specimens had a higher CD44 expression, aneuploid DNA content and high SPF, which demonstrated deposits of cervical metastatic lymph nodes. Conclusions: The CD44 and the flow cytometric analysis of the DNA ploidy correlation offer a significant prediction to determine the OSCC competence.
\end{abstract}

Keywords: CD44, Cancer Stem Cell, Flow Cytometry, DNA Ploidy, S-Phase Fraction.

\section{Introduction}

Oral squamous cell carcinoma (OSCC) is, particularly, the most familiar oral head and neck cancer worldwide. It always demonstrate a poor prognosis because of its late-stage diagnosis, local invasion and the recurrence of primary carcinomas. A study has revealed that the presence of lymph node metastasis is considered as the eventual and pivotal prognostic signal of survival and recurrence.[1] The assessment of lymph node status plays a crucial role in the treatment plan and the prediction of the patient survival. However, a part of hidden lymphatic metastases is still missed in investigation, which contribute in reducing the survival rate. [2, 3] However, in early-stage OSCC, the adoption of elective neck dissection has been questionable during the previous several decades. The regional lymph node metastasis through the pathologic evaluation is recognised in only a few patients. For those patients without lymph metastasis, the undesirable cosmetic and functional effects along with an increasing morbidity of neck dissection should be avoided. Thus, it is essential to meticulously predict lymph node metastasis before the surgery. [4] This phenomenon indicates the need for establishing other methods to determine the propensity for metastasis.

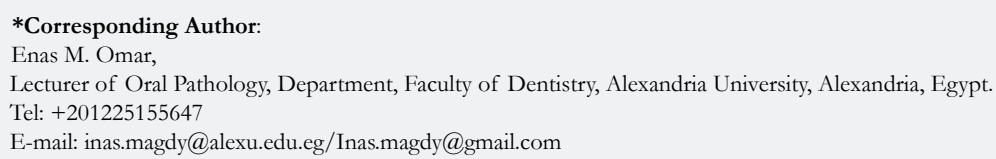

Citation: Ahmed M. Hussein, Asmaa M Zahran, Mohamed Badawy, Hany G. Gobran, Mohamed F. Edrees, Enas M. Omar. The Role of CD44 Cancer Stem Cell Marker in the Development and Progression of Lymph Node Metastasis in Oral Squamous Cell Carcinoma. Int J Dentistry Oral Sci. 2021;8(11):4917-4922. doi: http://dx.doi.org/10.19070/2377-8075-21000994

Copyright: Enas M. Omar ${ }^{\circ} 2021$. This is an open-access article distributed under the terms of the Creative Commons Attribution License, which permits unrestricted use, distribution and reproduction in any medium, provided the original author and source are credited. 
One of the theses regarding oral carcinogenesis and metastasis state that the neoplasm growth depends on cancer stem cells with self-renewal abilities that can advocate cancer initiation, advancementand metastasis. [5] Explicit markers for these cells such as CD44 were investigated to promote a profound understanding for CSCs' actions in carcinogenesis and metastasis. The CD44 is a cell surface glycoprotein assuming as a dominant receptor for hyaluronic acid. It participates in physiologic and pathologic processes such as lymphocyte homing, wound healing, angiogenesis and malignant diseases. It is also associated in cell attachment and migration. [6] The CD44 antigen is marked by the CD44 gene loaded on chromosome 11. Additionally, the CD44 is believed to be involved in cancer progression and metastasis as a regulator of growth, survival, differentiation, and migration. $[7,8]$

A great deal of interest has been directed towards using flow cytometric DNA analysis as an objective tool to study the natural history of SCC of the head and neck. Tumour DNA content is asserted to be one of the prognostic and metastatic indicators in this cancer. Several investigators have studied the same with respect to lymph node metastasis. [9-11] DNA ploidy has proven to be a useful prognostic indicator in various neoplasms.[12] The analysis of solid lesions by flow cytometry (FCM) permits rapid, objective, quantitative evolution and proliferative activity of cellular DNA content.[13] Neoplasms are usually classified according to their ploidy status into diploid types with a normal amount of DNA (2N) and aneuploid ones with an abnormal amount of DNA. Besides, the FCM also provides some assessment of cellular proliferative activity, defined by S-phase fraction (SPF), all of which may add a new dimension to the present pathologic and metastatic potentials of malignancy. [14] Computer-assisted cell cycle analysis by FCM provides the sensitivity for exposure near diploid/aneuploid peaks. FCM also possesses the advantage of allowing retrospective studies of paraffin-embedded tissue samples as well as from fresh or frozen tissue samples.[15] However, there are few reports on the relationship of flow cytometric analysis of nuclear DNA content of oral carcinomas with regional lymph node metastasis.

The objective of this research is to study the CD44 expression of CSCs and conduct flow cytometric analysis of nuclear DNA content of OSCC. This research further evaluates the diagnostic significance of these methods in anticipating the possibility of cervical lymph node metastasis.

\section{Materials and Methods}

This research was reviewed and approved by the institute's ethical; board (IORG\#:IORG0008839). The cases were retrospectively retrieved between 2015-2020 and obtained from incisional or excisional primary tumor biopsies during the same period of time from files of Oral Pathology Department, Faculty of Dentistry, Alexandria University over the last five years. Clinical data, including age, sex and site were obtained from the original pathology reports. Patients with OSCC who had at least one pathologically metastatic node were evaluated in a ratio of 50:50 (Group I). The remaining lesions with no data of any regional lymph node metastasis were categorised into Group II. Clinical staging, pathological differentiation and mode of infiltration of the primary carcinomas were defined based on the Union for International Cancer Control TNM Classification of Malignant Neoplasms and the
World Health Organization's classification.[16, 17$]$

In this study's tissue samples, one section having a thickness of 5 $\mu \mathrm{m}$ was cut from each block and stained with haematoxylin and eosin for the verification of diagnosis. Importantly, histopathological grading reassures that the neoplasm tissue constitutes more than $70 \%$ of the section, with minimal haemorrhagic andnecrotic foci. This step is essentialin obtaining accurate results and avoiding errors produced by analysing normal, inflammatory or necrotic tissues.

The tissue paraffin blocks were stained by an anti-CD44 antibody immunohistochemistry marker (Abcam, Cambridge, UK) to compare its different expressions among metastatic and non-metastatic lymph node OSCC. The staining steps were conducted while adhering to the universal immunostaining protocols. The strength of the CD44 immunoreaction was evaluated in terms of both means area (\%) and optical density by using the image analyser (Faculty of Oral and Dental Medicine, South Valley University). Each specimen was marked according to the power of the nuclear and cytoplasmic staining: no staining, 0 ; weak staining, + ; moderates taining, ++ ; and strong staining, +++ .

From each block, 3 pieces having a thickness of $50 \mu \mathrm{m}$ were cut and transmitted to the FCM Unit, Clinical Pathology Department, South Egypt Cancer Institute, Assiut University for flow cytometric analysis using Becton-Dickinson (B-D) FACS Calibur flow cytometer (USA). Specimens were stained by the cycle test ${ }^{\mathrm{TM}}$ plus DNA Reagent Kit (BD Biosciences). For each selected block, thickness of $50 \mu \mathrm{m}$ were placed into a labelled glass culture tube with dimensions of $16 \times 125 \mathrm{~mm}$. Nuclear suspensions of solid lesions were prepared using a modified version method. [18] The samples with a single G0/G1 peak were classified as DNA diploid. If two discrete G0/G1 peaks were present with an abnormal G0/G1 peak containing a minimum of $15 \%$ of the total events and having a corresponding $\mathrm{G} 2 / \mathrm{M}$ peak, then the neoplasms were considered as DNA aneuploidy.[19] The DNA index (DI) was recorded by the calculation programme for the DNA analysis system. The SPF is the fraction of the full cell residents that are present in the S-phase of the cell cycle and is usually asserted as a ratio. The cut-off for the SPF was set as the mean \pm 2 standard deviation (SD) and considered as either being low or high.

The data were collected, tabulated and statistically analysed using the SPSS system (release 11.0 software). All results were expressed as mean $\pm \mathrm{SD}$. One-way ANOVA was employed to test the data between the examined neoplasms. It was also used to analyse the mean CD44 area (\%) and the optical density of immunohistochemical results. The FCM variables between the research groups were compared using the Mann-Whitney U test and Kruskal-Wallis test. Chi-squared $( \pm 2)$ test was performed tocomparethe categorical data. $\mathrm{P}<0.05$ was considered significant in all the statistical results.

\section{Results}

This study was performed on 50 OSCC specimens at different clinical stages with variable histological grades. Half of the specimens with positive lymph node metastasis were identified (Figure 1). The increase in CD44 expression and aneuploidy state was powerfully associated with a higher stage and grade of disease, where as no relationship observed between CD44 immunoreac- 
tivity or aneuploidy state and patients' gender, age and neoplasm location (Table 1).

The immunoreaction to CD44 in the different tested groups showed variations in both mean area (\%) and the optical density (Figure 2). In Group I, the mean CD44 area was $66.14 \pm 7.54 \%$, and the mean CD44 optical density was $74.46 \pm 11.58$. A total of 16 specimens $(64 \%)$ exhibited strong staining $(+++) ; 7$ tumours $(28 \%)$ exhibited moderate staining $(++)$ and only 2 lesions $(8 \%)$ exhibited weak staining $(+)$. In Group II, the mean CD44 area was $44.06 \pm 7.43 \%$, and the mean CD44 optical density was 54.35 \pm 9.52. A total of 10 neoplasms $(40 \%)$ showed weak staining $(+)$; 9 tumours $(36 \%)$ showed moderate staining $(++)$ and 6 lesions $(24 \%)$ expressed strong staining $(+++)$. The differences in both mean CD44 area (\%) and optical density were highly statistically significant $(\mathrm{p}<0.0001)$, as shown in the comparison between Group I and Group II. As expected, the expression of CD44 was lower in non-metastatic cases (Group II) as compared to the metastatic lesions (Group I). Despite this result, it was noted that a decreased level of CD44 should not be considered exclusively for the possibility of lymph node metastasis.

In the flow cytometric analysis (Figure 3), 33 (66\%) lesions were found to have aneuploid cell populations and the remaining 17 tumours had a diploid cell population. Aneuploidy was observed in 19 out of $25(76 \%)$ specimens in Group I and in 14 out of 25 $(56 \%)$ tumours in Group II. The aneuploid neoplasms further were divided into: hyperdiploid with DI ranging from 1.05 to 1.82 with a mean of 1.45 (13 in Group I and 7 in Group II) and hypodiploid with DI ranging from 0.71 to 0.97 with a mean of 0.85 ( 6 in Group I and 7 in Group II). The difference in diploid and aneuploid DNA patterns (the ploidy state) between Group I and
Group II was statistically significant $(\mathrm{p}=0.002)$. There is no symbolic difference in the numbers of hyperdiploid and hypodiploidcases between Group I and Group II ( $p=0.657)$. The SPF values calculated for Group I ranged between $6.14 \%$ and $67.21 \%$ with a mean of $24.77 \%$, whereas the SPF values calculated for Group II ranged between $4.49 \%$ and $43.19 \%$ with a mean of $15.35 \%$. The S-phase values were furthered classified into high and low. About $72 \%$ (18 out of 25 ) of specimens in Group I had high SPF value (numbers of cells in SPF were equal or more than $24.77 \%$ ), and $28 \%$ (7 out of 25 ) of tumours had low SPF value. In Group II lesions, nearly $64 \%(16 / 25)$ of cases had high SPF (number of cells in SPF were more than 15.35\%), and 9 lesions(36\%) had low SPF values. There is no important difference in the mean SPF value of Group I and Group II specimens ( $\mathrm{p}=0.537)$.

There is a high significance difference $(p<0.0001)$ between the specimens with strong CD44 expression, aneuploid content and high SPF (64\%, in 16 out of 25) in Group I and the same examined lesions $(24 \%$, in 6 out of 25$)$ in Group II. This research result determined that the CD44 expression collaborates with the FCM analysis results of the tumour DNA content. Furthermore, this result establishes that CD44 expression is astrong diagnostic indicator for anticipating the qualification of oral cancer to produce cervical lymph node metastasis.

\section{Discussion}

Oral cancer exhibits an aggressive behaviour along with a high incidence of nodal metastasis, even in the initial stages, which always causes a poor prognosis.[20] The CSCs hypothesis states that CSCs exerted both regional and systemic effects on the can-

Figure 1. The CD44 Expression and Flow Cytometric Parameters between the Study Groups.

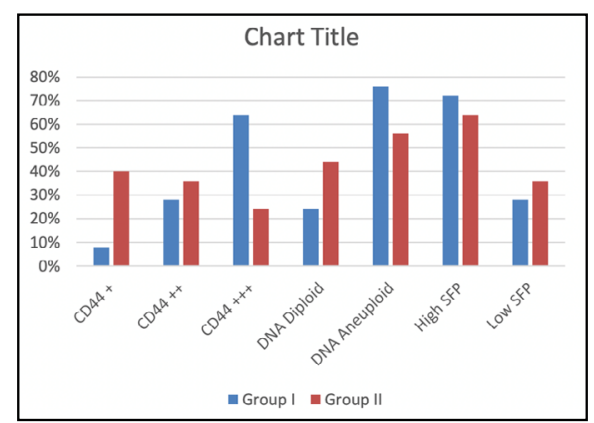

Figure 2. Different Fields in OSCC with Evident Lymph Node Metastasis. (A) Well-Differentiated OSCC at Group I (H\&E × 100); (B) Moderately Differentiated OSCC in the Form of Malignant Cell Nests at Group II (H\&E ×100); (C) Poorly Differentiated OSCC with Evident Malignant Criteria at Group I (H\&E ×400); (D, E and F) Different Fields of Cervical Lymph Node Metastasis from OSCC in Group I (H\&E ×100).

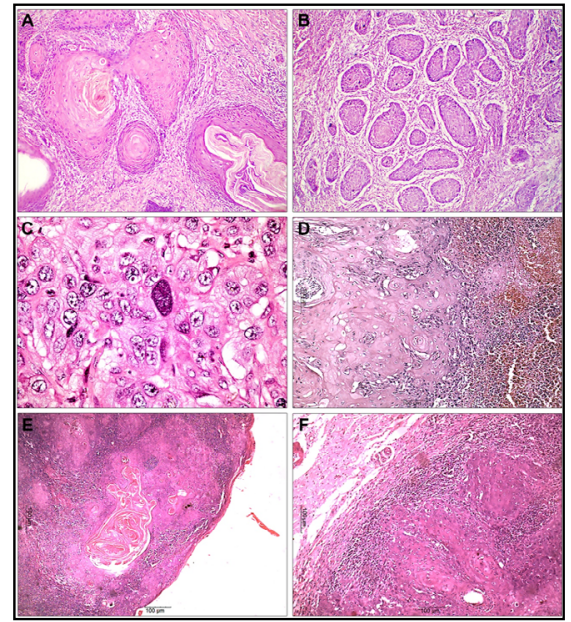


Figure 3. CD44 Expression in Different Fields of OSCC. (A) Strong Staining (+++) Group I, (B) Moderate Staining (++) Group I and (C) weak staining $(+)$ Group II. (Immunostained $\times 100)$.

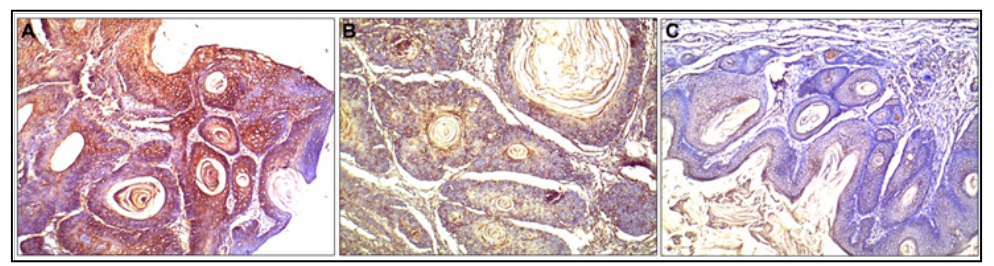

Figure 4. Different DNA Frequency Histograms. (A) High SPF (25.67\%) and Hyperdiploidpeak (DI= 1.12), Group I; (B) Low SPF (6.14\%) and hyperdiploid Peak (DI= 1.09), Group I; (C) Low SPF (16.23\%) and Hypodiploid Peak (DI= 0.79), Group I; (D)High SPF (9. 87\%) and Hypodiploid Peak (DI= 0.82), Group II; (E) High SPF (54.32\%) and Diploid Peak, Group I; (F) Low SPF (7.36\%) and Diploid Peak, Group II.

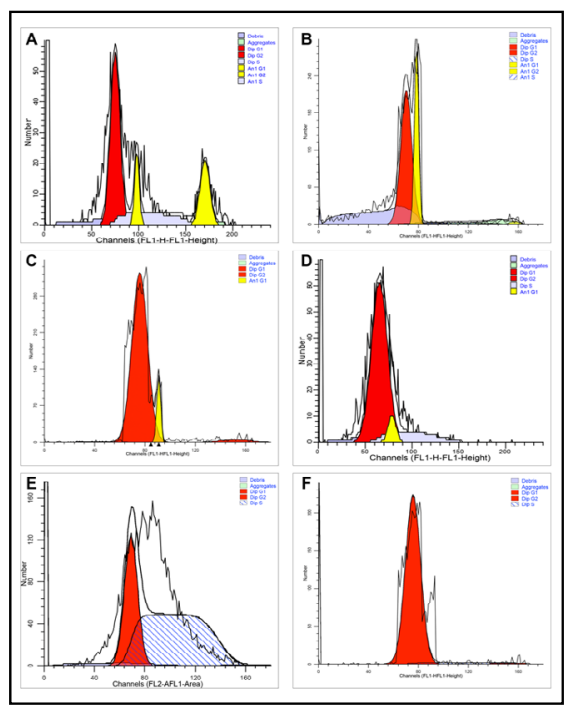

Table 1. Demographic Characteristics of Patients with Oral Cancer with Respect to CD44 Intensity and Flow Cytometric Parameters between the Study Groups.

\begin{tabular}{|c|c|c|c|c|c|c|c|c|c|c|}
\hline \multirow{3}{*}{ Group } & \multirow{3}{*}{\multicolumn{2}{|c|}{ Factor }} & \multirow{3}{*}{$\mathrm{Nu}$. } & \multicolumn{3}{|c|}{ CD44 } & \multicolumn{4}{|c|}{ Flow cytometry } \\
\hline & & & & \multirow{2}{*}{+} & \multirow{2}{*}{++} & \multirow{2}{*}{+++} & \multicolumn{2}{|c|}{ DNA Ploidy } & \multicolumn{2}{|c|}{ SPF } \\
\hline & & & & & & & Diploid & Aneuploid & High & Low \\
\hline \multirow{15}{*}{ Group I } & \multirow{2}{*}{ Sex } & Male & 15 & 2 & 5 & 8 & 2 & 13 & 11 & 4 \\
\hline & & Female & 10 & 0 & 2 & 8 & 4 & 6 & 7 & 3 \\
\hline & \multirow{2}{*}{ Age, years } & $>50$ & 8 & 1 & 3 & 4 & 3 & 5 & 3 & 5 \\
\hline & & $=0 \mathrm{r}<50$ & 17 & 1 & 4 & 12 & 3 & 14 & 15 & 2 \\
\hline & \multirow{6}{*}{ Location } & Tongue & 10 & 0 & 3 & 7 & 3 & 7 & 6 & 4 \\
\hline & & Mouth F. & 6 & 0 & 2 & 4 & 1 & 5 & 5 & 1 \\
\hline & & Alveolus & 4 & 1 & 1 & 2 & 1 & 3 & 3 & 1 \\
\hline & & Gingiva & 2 & 0 & 1 & 1 & 0 & 2 & 2 & 0 \\
\hline & & Palate & 2 & 1 & 0 & 1 & 1 & 1 & 1 & 1 \\
\hline & & B. mucosa & 1 & 0 & 0 & 1 & 0 & 1 & 1 & 0 \\
\hline & \multirow{3}{*}{ Histologically } & Well & 7 & 1 & 3 & 3 & 2 & 5 & 3 & 4 \\
\hline & & Moderate & 9 & 1 & 3 & 5 & 1 & 8 & 7 & 2 \\
\hline & & Poor & 9 & 0 & 1 & 8 & 3 & 6 & 8 & 1 \\
\hline & \multicolumn{2}{|c|}{ Group I } & \multirow{2}{*}{25} & 2 & 7 & 16 & 6 & 19 & 18 & 7 \\
\hline & 0 & & & $8 \%$ & $28 \%$ & $64 \%$ & $24 \%$ & $76 \%$ & $72 \%$ & $28 \%$ \\
\hline \multirow{15}{*}{ Group II } & \multirow{2}{*}{ Sex } & Male & 12 & 4 & 5 & 3 & 6 & 6 & 9 & 3 \\
\hline & & Female & 13 & 6 & 4 & 3 & 5 & 8 & 7 & 6 \\
\hline & \multirow{2}{*}{ Age, years } & $>50$ & 10 & 6 & 2 & 2 & 6 & 4 & 5 & 5 \\
\hline & & $=0 \mathrm{r}<50$ & 15 & 4 & 7 & 4 & 5 & 10 & 11 & 4 \\
\hline & \multirow{6}{*}{ Location } & Tongue & 7 & 2 & 2 & 3 & 2 & 5 & 4 & 3 \\
\hline & & Mouth F. & 8 & 3 & 3 & 2 & 2 & 6 & 7 & 1 \\
\hline & & Alveolus & 2 & 1 & 1 & 0 & 1 & 1 & 2 & 0 \\
\hline & & Gingiva & 3 & 2 & 1 & 0 & 2 & 1 & 2 & 1 \\
\hline & & Palate & 4 & 1 & 2 & 1 & 3 & 1 & 1 & 3 \\
\hline & & B. mucosa & 1 & 1 & 0 & 0 & 1 & 0 & 0 & 1 \\
\hline & \multirow{3}{*}{ Histologically } & Well & 12 & 7 & 4 & 1 & 8 & 4 & 5 & 7 \\
\hline & & Moderate & 8 & 2 & 3 & 3 & 2 & 6 & 7 & 1 \\
\hline & & Poor & 5 & 1 & 2 & 2 & 1 & 4 & 4 & 1 \\
\hline & \multicolumn{2}{|c|}{ Group II } & 25 & 10 & 9 & 6 & 11 & 14 & 16 & 9 \\
\hline & \multicolumn{2}{|c|}{$\%$} & 25 & $40 \%$ & $36 \%$ & $24 \%$ & $44 \%$ & $56 \%$ & $64 \%$ & $36 \%$ \\
\hline \multicolumn{3}{|c|}{ Total } & 50 & 12 & 16 & 22 & 17 & 33 & 38 & 12 \\
\hline \multicolumn{3}{|c|}{$\%$} & 50 & $24 \%$ & $32 \%$ & $44 \%$ & $34 \%$ & $66 \%$ & $76 \%$ & $24 \%$ \\
\hline
\end{tabular}


cer growth and metastasis.[21] CD44 was proposed as the ideal CSCs marker. The CSCs population identified by CD44 antibody expression was linked and parallel with the carcinogenesis process activity. It further contributed to aggressive cancer phenotypes. [22] This study's findings demonstrated a link between higher expression levels of CD44 and cervical lymph node metastasis of OSCC. Furthermore, this link has been shown to predict a poor survival and prognosis in patients with cancer. The CD44 expression plays a performative role in cancer aggressiveness and metastasis. A marked increase in the CD44 area (\%) and optical density was recorded in the examined tissues with lymph node metastatic deposits. The marker expression demonstrated a highly statistically value in the comparison between metastatic and non-metastatic lymph node OSCC. A high expression of CD44 could provide relevant information for the high competence of malignant cells that promote the progress of metastatic deposits.

In agreement with the our research results, Mirhashemi et al. observed a higher expression of CD44 and CD24 in OSCC, and revealed the possibility of malignant transformation.[23] Additionally, Judd et al. noted that the weak CD44 expression caused a delay in the carcinoma growth and metastasis.[24] Moreover, Cohen et al. tested the CD44 expression that presented as a prognostic aspect in oropharyngeal carcinomas.[25] Furthermore, comparable results reported by de Andrade et al. identified that the tissue cells with a strong CD44 expression had a higher capacity to form malignance.[26] Likewise, a study of oral cancer cell lines conducted by Ghuwalewala et al. revealed that the cell population with an intense CD44 expression enhanced a more tumorigenic potential along with invasive and metastatic skills. [27] Additionally, Paulis et al. concluded that the CD44 expression increased the aggressiveness of cancer cells behaviour. [28] $\mathrm{Li}$ et al.suggested that intense CD44 expression correlates to the advanced tumour grades, recurrence and poor prognosis. [29] This observation goes in line with the results of our research. In contrast, Krump et al. demonstrated that there are no serious differences in CD44 reactions between the different carcinoma grades in the oral cavity.[30] This shortening in the appearance of CD44 may be attributed to the improper selection of the examined tissues that may have massive areas of inflammation, further leading to a false result in the CD44 expression. Moreover, the difference in the examined tissue and the sorting techniques with that of immunohistochemistry for identifying the CD44 expression in tissue such as Western blotting and flow cytometric assessments may have validated different sorting results.

This study demonstrated that the differences in DNA ploidy was highly statistically significant $(p<0.0001)$ as revealed in the comparison between Group I (metastatic lymph node OSCC) and Group II (non-metastatic lymph node OSCC). The research results are compatible with El-Deftar et al.s findings. [31] Furthermore, Hayry et al.'s results indicate that the nuclear morphometric features and analysis of DNA ploidy of the nodal tissue by FCM mainly help as the prognostic metastatic markers of oral cancer. [32] Supporting data published by Kamphues et al. reported that the DI represents an independent prognostic marker both postand preoperatively. It might become a potential tool in the preoperative decision-making process. [33] Furthermore, Jagric et al. concluded that FCM is a rapid, cost-effective, widely obtainable and highly distinct method for sentinel lymph node metastases. Therefore, it cannot be recommended as the only test for detecting lymph node metastases before surgeries. [34] Moreover, A costa et al. concluded that the finding of positive aneuploid cells using FCM strongly indicates the presence of carcinoma cells. [35]. Additionally, Missaoui et al. showed that DI and SPF appear helpful in making the distinction between benign and malignant lesions, and aneuploidy appears to be more interesting in the prognosis evaluation of these neoplasms.[36] However, Ludovini et al. do not support the prognostic aspect of DNA ploidy to spot patients with more aggressive tumours who are at a high risk for disease relapse and metastases.[37] Furthermore, Zargoun et al. reported that DNA ploidy alone was not specific and may not be a good tool to evaluate prognosis or metastatic progression in oral cavity carcinomas. [38] This result is in agreement with our findings, which recorded that the collaboration between the CD44 immunohistochemical expression and the DNA analysis by FCM was more effective in predicting the capability of the malignant cell to promote lymph node metastases.

Our finding showed that there was no important relationship between the SPF of the metastatic and non-metastatic lymph node cases. This result agrees with Zahran et al.'s results, which expressed that the DNA aneuploidy may be a key indicator for tumour activity and malignancy in salivary gland tumours with no significant SPF value in evaluating tissue activity.[39] Similarly, Pinto et al. report a borderline significance of SPF with respect to the overall survival and loco-regional lymph node metastasis of papillary thyroid carcinoma.[40] In different circumstances, Pervez et al. found that the SPF was a more reliable marker in anticipating the axillary lymph node metastases in breast carcinomas.[41] Oya et al. also demonstrated that the DNA ploidy is heterogeneous within a cancer, whereas SPF is relatively stable and can be correlated with regional metastasis in oral cancer.[42]

Lymph node metastasis is a convoluted progression of events. Initially, cancer cells penetrate their adjacent tissues and move through the lymphatic vessels. Finally, they are carried to the cervical lymph nodes where they must be deposited and grow to form metastatic lesions. The chance of evolution of each cell population would be higher with heterogeneous tumours. [43, 44] At the time of diagnosis, malignant neoplasms have undergone various changes during progression and usually contain subpopulations of cells with different biologic features. Obviously, aneuploid carcinomais more heterogeneous than the diploid one in terms of cell populations. This may be the reason for the higher incidence of lymph node metastasis shown by the aneuploid carcinomas as compared to the diploid one.

\section{Conclusions}

In conclusion, the immunoexpression of CD44 was found in all the OSCC samples. The high CD44 expression was compelling and associated with a higher stage of lymph node metastasis. The state of DNA ploidy can possibly advance our prediction of oral cancer strength to establish lymph node metastasis.

Further studies regarding the anticipation of the oral cancer metastasis will definitely increase therapeutic success while effectively decreasing morbidity and mortality of OSCC.

Funding: This research did not receive any specific grant from funding agencies in the public, commercial or not-for-profit sectors. 


\section{References}

[1]. Akhter M, Hossain S, Rahman QB, Molla MR. A study on histological grading of oral squamous cell carcinoma and its co-relationship with regional metastasis. J Oral MaxillofacPathol. 2011 May;15(2):168-76.

[2]. Singh A, Mair M, Singhvi H, Mahuvakar A, Nair D, Nair S, et al. Incidence, predictors and impact of positive bony margins in surgically treated T4 stage cancers of the oral cavity. Oral Oncol. 2019 Mar;90:8-12.Pubmed PMID: 30846181.

[3]. Biswas NK, Das C, Das S, Maitra A, Nair S, Gupta T, et al. Lymph node metastasis in oral cancer is strongly associated with chromosomal instability and DNA repair defects. Int J Cancer. 2019 Nov 1;145(9):2568-2579. Pubmed PMID: 30924133

[4]. Lee BS, Jang JY, Seo C, Kim CH. Crosstalk between head and neck cancer cells and lymphatic endothelial cells promotes tumor metastasis via CXCL5-CXCR2 signaling. FASEB J. 2021 Jan;35(1):e21181.Pubmed PMID: 33231340 .

[5]. Li YC, Chang JT, Chiu C, Lu YC, Li YL, Chiang CH, et al. Areca nut contributes to oral malignancy through facilitating the conversion of cancer stem cells. Mol Carcinog. 2016 May;55(5):1012-23.Pubmed PMID: 26087469.

[6]. Boxberg M, Götz C, Haidari S, Dorfner C, Jesinghaus M, Drecoll E, et al. Immunohistochemical expression of CD44 in oral squamous cell carcinoma in relation to histomorphological parameters and clinicopathological factors. Histopathology. 2018 Oct;73(4):559-572.Pubmed PMID: 29468726.

[7]. Wang Z, Zhao K, Hackert T, Zöller M. CD44/CD44v6 a Reliable Companion in Cancer-Initiating Cell Maintenance and Tumor Progression. Front Cell Dev Biol. 2018 Aug 28;97(6):1-28.Pubmed PMID: 30211160.

[8]. Chen C, Zhao S, Karnad A, Freeman JW. The biology and role of CD44 in cancer progression: therapeutic implications. J Hematol Oncol. 2018 Dec;11(1):64.

[9]. Pillai V, Dorfman DM. Flow cytometry of nonhematopoietic neoplasms. Acta cytologica. 2016;60(4):336-43

[10]. Hussein AM, El-Sheikh SM, Attia MA, Ramadan OR, Omar EM, Gaber AH. Analysis of DNA ploidy and S-phase fraction in relation to development of oral squamous cell carcinoma: an experimental study. EgyptDentJ. 2019 Jul 1;65:513-21.

[11]. Velidandla S, Manikya S, Gajjada N, Reddy S, Gogulamudi L, Mediconda S. Correlation between histological grading and ploidy status in oral leukoplakia, oral submucous fibrosis, and oral squamous cell carcinoma: a flow cytometric analysis. J Pharm Bioallied Sci. 2020 Aug;12(Suppl 1):S91-S98. Pubmed PMID: 33149437

[12]. Aebisher D, Bartusik D, Tabarkiewicz J. Laser flow cytometry as a tool for the advancement of clinical medicine. Biomed Pharmacother. 2017 Jan 1;85:434-43.

[13]. Chang Q, Hedley D. Emerging applications of flow cytometry in solid tumor biology. Methods. 2012 Jul 1;57(3):359-67.

[14]. García Martínez J, García-Inclán C, Suárez C, Llorente JL, Hermsen MA. DNA aneuploidy-specific therapy for head and neck squamous cell carcinoma. Head Neck. 2015 Jun;37(6):884-8.Pubmed PMID: 24623685.

[15]. Lee H, Rabinovitch PS, Mattis AN, Kakar S, Choi WT. DNA flow cytometric analysis of paraffin-embedded tissue for the diagnosis of malignancy in bile duct biopsies. Hum. Pathol. 2020 May 1;99:80-7.

[16]. Huang SH, O'Sullivan B. Overview of the 8th edition TNM classification for head and neck cancer. Curr Treat Options Oncol. 2017 Jul;18(7):40.

[17]. Reichart P, Sciubba JJ, Philipsen HP. Splitters or lumpers: the 2017 WHO Classification of Head and Neck Tumours. J Am Dent Assoc. 2018 Jul 1;149(7):567-71

[18]. Darzynkiewicz Z, Huang X, Zhao H. Analysis of cellular DNA content by flow cytometry. CurrProtoc Immunol. 2017 Nov;119(1):5-7.

[19]. Castagnola P, Zoppoli G, Gandolfo S, Monticone M, Malacarne D, Cirmena G, et al. Genomic DNA Copy Number Aberrations, Histological Diagnosis, Oral Subsite and Aneuploidy in OPMDs/OSCCs. PLoS One. 2015 Nov 5;10(11):e0142294.Pubmed PMID: 26540282.

[20]. Bhuyan L, Sarangi S, Das BK, Das SN, Nayak S. Proliferative Index in Invasive Tumor Front of Oral Squamous Cell Carcinoma: A Potential Prognostic Indicator. J Contemp Dent Pract. 2018 Feb 1;19(2):170-176.Pubmed PMID: 29422466

[21]. Stoica G. Cancer stem cells: Current status and future directions. Vet J. 2015;2(205):124-5.

[22]. Wang L, Zuo X, Xie K, Wei D. The role of CD44 and cancer stem cells. Methods Mol Biol. 2018: 31-42.

[23]. Mirhashemi M, Ghazi N, Saghravanian N, Taghipour A, Mohajertehran F. Evaluation of CD24 and CD44 as cancer stem cell markers in squamous cell carcinoma and epithelial dysplasia of the oral cavity by q- RT-PCR. Dent Res J (Isfahan). 2020 May 23;17(3):208-212.Pubmed PMID: 32774798.
[24]. Judd NP, Winkler AE, Murillo-Sauca O, Brotman JJ, Law JH, Lewis JS Jr, et al. ERK1/2 regulation of CD 44 modulates oral cancer aggressiveness. Cancer Res. 2012 Jan 1;72(1):365-74.Pubmed PMID: 22086849.

[25]. Cohen ER, Reis IM, Gomez C, Pereira L, Freiser ME, Hoosien G, et al. Immunohistochemistry Analysis of CD44, EGFR, and p16 in Oral Cavity and Oropharyngeal Squamous Cell Carcinoma. Otolaryngol Head Neck Surg. 2017 Aug; 157(2):239-251.Pubmed PMID: 28397583.

[26]. de Andrade NP, Rodrigues MF, Rodini CO, Nunes FD. Cancer stem cell, cytokeratins and epithelial to mesenchymal transition markers expression in oral squamous cell carcinoma derived from ortothopic xenoimplantation of CD44high cells. Pathol Res Pract. 2017 Mar;213(3):235-244.Pubmed PMID: 28214216

[27]. Ghuwalewala S, Ghatak D, Das P, Dey S, Sarkar S, Alam N, et al. CD44(high)CD24(low) molecular signature determines the Cancer Stem Cell and EMT phenotype in Oral Squamous Cell Carcinoma. Stem Cell Res. 2016 Mar; 16(2):405-17.Pubmed PMID: 26926234.

[28]. Paulis YW, Huijbers EJ, van der Schaft DW, Soetekouw PM, Pauwels P, Tjan-Heijnen VC, et al. CD44 enhances tumor aggressiveness by promoting tumor cell plasticity. Oncotarget. 2015 Aug 14;6(23):19634-46.

[29]. Li X, Ma X, Chen L, Gu L, Zhang Y, Zhang F, et al. Prognostic value of CD44 expression in renal cell carcinoma: a systematic review and meta-analysis. Sci Rep. 2015 Aug 19;5:13157-64.Pubmed PMID: 26287771.

[30]. Krump M, Ehrmann J. Differences in CD44s expression in HNSCC tumours of different areas within the oral cavity. Biomed Pap Med Fac Univ Palacky Olomouc Czech Repub. 2013 Dec;157(4):280-3.Pubmed PMID: 23235720.

[31]. El-Deftar MF, El Gerzawi SM, Abdel-Azim AA, Tohamy SM. Prognostic significance of ploidy and S-phase fraction in primary intraoral squamous cell carcinoma and their corresponding metastatic lymph nodes. J Egypt Natl Canc Inst. 2012 Mar;24(1):7-14.Pubmed PMID: 23587227.

[32]. Häyry V, Kågedal Å, Hjalmarsson E, Neves da Silva PF, Drakskog C, Margolin $\mathrm{G}$, et al. Rapid nodal staging of head and neck cancer surgical specimens with flow cytometric analysis. Br J Cancer. 2018 Feb 6;118(3):421-427.Pubmed PMID: 29161240.

[33]. Kamphues C, Al-Abadi N, Bova R, Rademacher S, Al-Abadi H, Klauschen $\mathrm{F}$, et al. The DNA index as a prognostic tool in hilar cholangiocarcinoma. J Surg Oncol. 2015 Aug;112(2):214-8.Pubmed PMID: 26220797.

[34]. Jagric T, Mis K, Gorenjak M, Goropevsek A, Kavalar R, Mars T. Can flow cytometry reinvent the sentinel lymph node concept in gastric cancer patients? J Surg Res. 2018 Mar;223:46-57.Pubmed PMID: 29433885.

[35]. Acosta M, Pereira J, Arroz M. Screening of carcinoma metastasis by flow cytometry: A study of 238 cases. Cytometry B Clin Cytom. 2016 May;90(3):289-94.Pubmed PMID: 26054018.

[36]. Missaoui N, Hmissa S, Mokni M, Trabelsi A, Trimech M, Lagueb I, et al. DNA content analysis in thyroid neoplasms: diagnostic and prognostic interest. Ann Endocrinol. 2005 Sep 1; 66(4): 333-339.

[37]. Ludovini V, Pistola L, Gregorc V, Floriani I, Rulli E, Di Carlo L, et al. Biological markers and DNA flow cytometric analysis in radically resected patients with non-small cell lung cancer. A study of the Perugia Multidisciplinary Team for Thoracic Tumors. Tumori. 2008 May-Jun;94(3):398-405. Pubmed PMID: 18705409.

[38]. Zargoun IM, Bingle L, Speight PM. DNA ploidy and cell cycle protein expression in oral squamous cell carcinomas with and without lymph node metastases. J Oral Pathol Med. 2017 Oct;46(9):738-43.

[39]. Zahran AM, Fakhry H, Hussein KA, Abd El-Salam M, Mohamed MA, Tohamy SM. Flow cytometry analysis of DNA ploidy and S-phase fraction in salivary gland tumors of Egyptian patients. Clin Oncol. 2018;3:1393-8.

[40]. Pinto AE, Silva GL, Pereira T, Cabrera RA, Santos JR, Leite V. S-phase fraction and ploidy as predictive markers in primary disease and recurrence of papillary thyroid carcinoma. Clin Endocrinol (Oxf). 2012 Aug;77(2):302-9. Pubmed PMID: 22329804.

[41]. Pervez S, Khan MN, Nasir MI. Comparative predictive value of three prognostic markers--S-phase fraction, PCNA and Mitotic count on axillary lymph node metastasis in carcinoma breast. J Ayub Med Coll Abbottabad. 2007;19(1):3-5.

[42]. Oya R, Ikemura K. Can flow cytometrically determined DNA ploidy and Sphase fraction predict regional metastasis in squamous cell carcinoma of the oral cavity? Head Neck. 2002 Feb;24(2):136-42.Pubmed PMID: 11891943.

[43]. Roy P, Mallick I, Arun I, Zameer L, Dey D, Singh A, et al. Nodal yield and topography of nodal metastases from oral cavity squamous cell carcinoma An audit of 1004 cases undergoing primary surgical resection. Oral Oncol. 2020;113:105-15.

[44]. Hoda N, Rajani BC, Ghosh S, Sabitha KS, Vasantha Dhara B, Nathani J. Cervical lymph node metastasis in squamous cell carcinoma of the buccal mucosa: a retrospective study on pattern of involvement and clinical analysis. Med Oral Patol Oral Cir Bucal. 2021 Jan;26(1):e84-9. 